\title{
Tocolysis for preterm labor: Expert opinion
}

\author{
Irène Hösli • Christiane Sperschneider · \\ Gero Drack • Roland Zimmermann • \\ Daniel Surbek · Olivier Irion
}

Received: 9 July 2013/ Accepted: 13 December 2013/Published online: 3 January 2014

(C) Springer-Verlag Berlin Heidelberg 2014

\begin{abstract}
Tocolysis is an important treatment in the improvement of outcome in preterm labor and preterm birth, provided that its use follows clear evidence-based recommendations. In this expert opinion, the most recent evidence about efficacy and side effects of different tocolytics is being reviewed and evidence-based recommendation about diagnosis and treatment of preterm labor is given. Further aspects such as progesterone administration or antibiotic treatment for the prevention of preterm birth are included. Our review demonstrates that an individualized choice of different tocolytics and additional treatments is necessary to improve short- and long-term neonatal outcome in preterm labor and preterm birth.
\end{abstract}

Keywords Tocolysis $\cdot$ Preterm labor $\cdot$ Preterm birth

\section{Introduction}

This Expert Opinion Letter gives current evidence-based recommendations on indication and selection of tocolytics.

The incidence of preterm birth, i.e., delivery before 37 weeks of gestation, in Switzerland lies around $7.5 \%$, with $1 \%$ occurring before 32 weeks of gestation [1]. This puts Switzerland in the middle of the pack compared with the rate of prematurity in Europe as a whole (5.5-11.4 \%).

Committee for Quality Assurance of the Swiss Society of Obstetrics and Gynecology.

I. Hösli · C. Sperschneider · G. Drack · R. Zimmermann ·

D. Surbek $(\bowtie) \cdot$ O. Irion

Committee for Quality Assurance, Swiss Society of Obstetrics

and Gynecology, Department of Obstetrics and Gynecology,

University Hospital Inselspital, Effingerstrasse 102, 3010

Bern, Switzerland

e-mail: daniel.surbek@insel.ch
Prematurity accounts for about $75 \%$ of perinatal mortality and for about $50 \%$ of long-term morbidity [2].

It is often difficult to identify the pregnant women at high risk for preterm birth in time to prevent it. Approximately $90 \%$ of women presenting with contractions will not deliver within the next 7 days and about $75 \%$ of them will reach term without tocolysis or any other therapies [3].

Many pregnant women with preterm contractions are thus "over-treated". The goal must therefore be the identification of the women who are truly at risk of going on to preterm birth to prevent unnecessary and costly interventions.

Only the timely recognition of an impending preterm birth allows for a risk-specific management with stabilization of the pregnant woman and transfer to a specialized perinatology unit. About a third of all preterm births are medically indicated (preeclampsia, intrauterine growth retardation, etc.). Approximately $40-50 \%$ are the results of preterm labor and a further $30 \%$ occur after preterm rupture of membranes before 37 weeks of gestation. The recommendations presented concern predominantly the latter two groups.

The management of threatened preterm birth consists of:

- Diagnostic procedures to evaluate the risk and plan appropriate therapy.

- Initiation of tocolysis.

- Administration of corticosteroids to promote fetal lung maturity [4].

- Possible administration of antibiotics.

- Transfer to a specialized perinatal center.

\section{Diagnosis}

The following diagnostic procedures are mandatory: 
1. Medical history: Identification of women at high risk, i.e., with multiple gestations, uterine malformations, fibroids, or a history of previous preterm birth, second trimester pregnancy loss, induced abortions, and repeated uterine curettage, conization, or other cervical procedures. Careful documentation of complications in the current pregnancy as well as the actual complaints at presentation such as lower abdominal cramping, back pain, and vaginal discharge $[5,6]$.

2. CTG: Assessment of fetal wellbeing and uterine activity.

3. Abdominal ultrasound examination: Position, weight, morphology of the fetus, position and morphology of the placenta, amount of amniotic fluid, Doppler evaluation of placental and fetal circulation.

4. Speculum Exam: Evaluation of possible bleeding, amniotic fluid leak, prolapse of fetal membranes. To obtain material for cultures. Fetal fibronectin test and tests for presence of amniotic fluid are optional (see below).

5. Endovaginal Sonography: Evaluation of cervical length, evaluation/exclusion of placenta previa, and vasa previa.

6. Blood tests: CRP and leucocytes for exclusion of amniotic fluid infection syndrome.

Transvaginal ultrasound is superior to digital examination in the detection of impending premature birth [7-9]. In the presence of preterm rupture of membranes, all vaginal examinations (speculum or sonography) should be restricted as much as possible and only conducted under strictly sterile conditions [10, 11]. Digital examination should be avoided before delivery is under way. If after history, speculum exam and sonography there is still uncertainty as to the presence of preterm rupture of membranes, immune-chromatological tests (AmniSure ${ }^{\circledR}$, Actim Prom test ${ }^{\circledR}$ ) are recommended [12].

\section{Indications for tocolysis $(24+0-33+6$ weeks of gestation)}

The use of tocolytics before 24 weeks of gestation can be justified in individual cases (i.e., preoperatively with cervical cerclage). The use of tocolytics during external version for breech position, for the intrauterine reanimation or for the delivery of the baby during cesarian section will not be addressed in this Expert Opinion Letter.

For initiation of tocolysis one or more of the following criteria must be met:

- Preterm spontaneous labor (CTG $>4$ uterine contractions in $20 \mathrm{~min}$, or 6 in $60 \mathrm{~min}$ ) and one of the following:

- Shortening of the functional length of the cervix to $\leq 25 \mathrm{~mm}$, or shortening of the cervix by $>5 \mathrm{~mm}$ (by transvaginal sonography) over the course of $2 \mathrm{~h}$.

- Positive fibronectin test (optional).
- Symptomatic placenta previa/low lying placenta with vaginal bleeding.

- Cervical dilatation of $>2 \mathrm{~cm}$ and $<5 \mathrm{~cm}$.

- Preterm spontaneous rupture of membranes prior to 34 weeks of gestation without signs of chorioamnionitis (optional indication, no general recommendation).

In unclear situations, the measuring of fetal fibronectin may provide further guidance on how to proceed. The risk of preterm birth rises to $50 \%$ with gestational age of $\leq 32$ weeks, cervical length of $\leq 15 \mathrm{~mm}$, and a positive fibronectin test. If the fibronectin test is negative and cervical length is $15 \mathrm{~mm}$, the risk of delivery within the next 7 days drops to $\leq 1 \%$ [13-15]. With a cervical length of $\geq 25 \mathrm{~mm}$ and a negative fibronectin test at 24 weeks of gestation, the risk of preterm birth is minimal based on a negative predictive value of $>95 \%$ [16]. Other biochemical tests including IGFBP-1 (insulin growth factor binding protein-1) and PAMG-1 (placental alpha microglobulin-1) have similar predictive values in the diagnosis of "true" preterm labor, and can be used clinically.

\section{Goal of tocolysis}

The primary goal of a tocolysis is the prevention of a preterm delivery before the end of the 37 th week of gestation. As this goal is often not obtainable, tocolysis should aim for prolonging the pregnancy to 34 weeks of gestation, or at the very least by $48 \mathrm{~h}$ to allow for one-time administration of Betamethasone (Celestone ${ }^{\circledR}$ ), $2 \times 12 \mathrm{mg}$ i.m. $24 \mathrm{~h}$ apart, which can reduce perinatal mortality and morbidity by as much as $50 \%$ [17]. A further goal of tocolysis is making it possible to transfer the fetus in utero to a specialized perinatal center which further significantly reduces perinatal mortality and morbidity. Conversely, the fetus should not sustain any damage from remaining in a hostile intrauterine environment (i.e., due to infection!); under these circumstances, a prolongation of the pregnancy through tocolysis would not be appropriate.

Contraindications to tocolysis [18]

\begin{tabular}{ll}
\hline $\begin{array}{l}\text { Maternal indications for } \\
\text { ending the pregnancy }\end{array}$ & $\begin{array}{l}\text { Fetal indications for ending the } \\
\text { pregnancy }\end{array}$ \\
\hline $\begin{array}{l}\text { Sepsis } \\
\text { Severe preeclampsia }\end{array}$ & $\begin{array}{l}\text { Pathological CTG } \\
\text { Premature placental separation (relative } \\
\text { contraindication) }\end{array}$ \\
$\begin{array}{l}\text { Maternal hemodynamic } \\
\text { instability }\end{array}$ & $\begin{array}{l}\text { Chorioamnionitis } \\
\text { Pulmonary edema }\end{array}$ \\
& $\begin{array}{c}\text { Intrauterine fetal demise or fetal } \\
\text { malfermations not compatible with }\end{array}$ \\
\hline
\end{tabular}


Acute tocolysis

Tocolytics manage to delay delivery by 24 to max. 7 days. However, so far no reduction of the rate of preterm birth before 32, resp., 37 weeks of gestation, or of neonatal morbidity (respiratory distress syndrome or intraventricular hemorrhage) and/or perinatal mortality could be documented in randomized placebo-controlled trials for the various beta-sympathomimetics, oxytocin receptor agonists or prostaglandin synthesis inhibitors [19]. This lack of demonstrable benefit for the neonate can be explained though by methodological weaknesses in the RCTs published thus far [20]. The positive effect on morbidity and mortality of the transfer to a specialized perinatal center made possible by tocolysis and the induction of lung maturity is not taken into account either. According to the current state of knowledge, all the listed tocolytics are equally efficacious in regards to suppression of labor and their selection should be on the basis of absolute and relative contraindications for their use is a given patient. Calcium antagonists appear to have a better neonatal outcome than beta-sympathomimetics, though long-term outcome data are lacking [21]. Beta-sympathomimetics and oxytocin receptor antagonists are approved in Switzerland for tocolysis, whereas the use of calcium antagonists for tocolysis is an off-label indication, which has to be disclosed and explained to the patient before starting them.

The need for a change in treatment (rescue therapy, nonresponse to a tocolytics), the general attitude in a specific institution, or economic criteria may all influence the choice of tocolytic [22]. The lack of evidence justifies a restricted use of tocolytics. A combination of different tocolytics should generally be avoided because such combination may potentiate severe adverse effects [22, 23].

Tocolytics with promising data

\section{Beta-Sympathomimetics}

Intravenously administered beta-sympathomimetics (hexoprenaline, fenoterole) have a documented tocolytic effect, though when compared to placebo or oxytocin receptor antagonists, they clearly have a higher rate of maternal adverse effects based on their mechanism of action (palpitations in $48 \%$, tremor in $39 \%$, headache in $23 \%$, chest pain in $10 \%$ of patients). In combination with corticosteroids and excessive i.v. fluid administration (especially in the presence of infection) they also have a higher risk (1:425) of pulmonary edema [19, 20]. By administering tocolysis in bolus form or through fluid restriction, the rate of maternal adverse effects can be reduced [24]. Fetal adverse effects include transient tachycardia or hypoglycemia when beta-sympathomimetics were administered within 2 days of delivery [22]. It is therefore recommended to use them for a restricted duration and dosage under strict volume control [25]. There is no documented efficacy of beta-sympathomimetics when given orally.

Specific contraindications for beta-sympathomimetics are:

- Cardiac disease including arrhythmias.

- Thyrotoxicosis.

- Severe preeclampsia.

- Uncontrolled diabetes mellitus (cave; exacerbation of hyperglycemia).

- Pulmonary edema.

- Multiple gestation (relative contraindication).

- Severe anemia.

\section{Oxytocin receptor antagonists}

Oxytocin receptor antagonists have comparable tocolytic efficacy to beta-sympathomimetics, but with markedly fewer maternal adverse effects $[26,27,28]$ and have an optimal risk-benefit profile. Palpitations occur in $2 \%$, tachycardia in $6 \%$, and headache in $10 \%$ of patients. Severe adverse effects have not been reported for use of oxytocin receptor antagonists alone [22]. For this reason they are considered, together with calcium antagonists, the first line tocolytic by many international specialty societies. In high-risk situations (elevated risk for pulmonary edema, in multiple gestations, with polyhydramnios, cardiac or pulmonary disease, diabetes mellitus I, persistent contractions, and/or tachycardia with hexoprenaline) atosiban should be the first line tocolytic. Atosiban is administered i.v. in a loading dose of $6.75 \mu \mathrm{g}$ over $1 \mathrm{~min}$, followed by $3 \mathrm{~h}$ of $18 \mathrm{mg}$ per hour and thereafter as a maintenance dose of $6 \mathrm{mg} / \mathrm{h}$ for $45 \mathrm{~h}$. The total treatment time should not exceed $48 \mathrm{~h}$. The maximal dose for a single course should not exceed $330 \mathrm{mg}$. The price is significantly higher than for other tocolytics.

\section{Calcium antagonists}

Calcium antagonists have, compared to beta-sympathomimetics, a better risk-benefit profile, i.e., equal efficacy in regards to prolongation of pregnancy with a low rate of maternal and fetal adverse effects. For this reason they are recommended by various international specialty societies, together with oxytocin receptor antagonists, as first line tocolytics [20, 29, 30]. It is also important to notice that calcium antagonists are the only tocolytic that can be given orally. This, however, has only been 
documented with nifedipin (but not for other calcium antagonists) in comparison with other tocolytics [31]. Compared to beta-sympathomimetics, nifedipin improves neonatal morbidity (respiratory distress syndrome, intraventricular hemorrhage, necrotizing enterocolitis) and has fewer maternal adverse effects [32]. Based on the lack of long-term outcome data and because of the question regarding the optimal dosage there is still a need for further and larger scale studies. Adverse effects include lowering of blood pressure (cave: orthostatic vertigo) and headaches. Severe adverse reactions in the form of pulmonary edema have been observed, especially in twin pregnancies.

Current recommendations call for nifedipin slow release (Adalat $\mathrm{CR}^{\circledR}$ ) with a loading dose of $30-40 \mathrm{mg}$ p.o. (10 mg every 10-15 $\mathrm{min}$ ) during the first hour, then $60 \mathrm{mg}$ a day up to a maximal dose of 120-150 mg per day [33]. An alternative regimen consists of nifedipin $10 \mathrm{mg}$ to chew, combined with $20 \mathrm{mg}$ nifedipin slow release (Adalat $\mathrm{CR}^{\circledR}$ ) for a rapid saturation; after $60 \mathrm{~min}$ a maintenance dose of $60 \mathrm{mg}$ nifedipin low release is given and $30 \mathrm{mg}$ nifedipin slow release kept in reserve [34]. A maintenance dose of $90 \mathrm{mg}$ nifedipin slow release (alternating $30 \mathrm{mg}$ and $60 \mathrm{mg}$ every $12 \mathrm{~h}$ ) also was well tolerated $[35,36]$. Nifedipin can be combined with high dose magnesium sulfate (i.e., with preeclampsia) [37]. [38]:

Specific contraindications for calcium antagonists are

- Cardiac disease including arrhythmias.

- Arterial hypertension.

- Pulmonary edema.

- Multiple gestation (relative contraindication).

- Intrauterine growth retardation $(<5$ th percentile).

\section{Tocolytics with limited data, despite documentation of tocolytic effect}

Prostaglandin synthesis inhibitors

Prostaglandin synthesis inhibitors (especially indomethacin) have been used for tocolysis. In randomized studies a significantly better tocolytic effect compared to placebo and at least comparable with that of other tocolytics was documented. However, the subject numbers are too small to give a clear recommendation [39, 40]. Possible fetal adverse effects include impaired renal function (with subsequent oligohydramnios) and the constriction of the ductus arteriosus; they should therefore not be used for longer than $48 \mathrm{~h}$. Recommended are $100 \mathrm{mg}$ as a loading dose followed by $50 \mathrm{mg}$ every $6-8 \mathrm{~h}$.
Specific contraindications to indomethacin are:

- Gestational age $>32$ weeks.

- Current or past gastric ulcer.

- Hypertension.

- Allergy to NSAIDs.

- Severe intrauterine growth retardation.

- Oligohydramnios.

\section{Nitric oxide donor drugs}

Even though NO-donors (transdermal with NitroTTS patch) were able to show in an RTC a significant reduction in neonatal morbidity with preterm birth before 28 weeks of gestation, there is not yet sufficient evidence of the efficacy of using them as tocolytics outside of a study setting [41]. The most common adverse effect is therapy resistant headache.

Tocolytics without demonstrated tocolytic effect

\section{Magnesium sulfate}

There is no definitively proven effect of magnesium sulfate as a tocolytic. The effects of magnesium on tocolysis have yielded contradictory results in clinical studies [42, 43]. Nevertheless, magnesium is, unlike in Europe, the most commonly used tocolytic in the USA. The usual initial dose of $6 \mathrm{~g}$ i.v. over $20 \mathrm{~min}$ is generally followed by a maintenance dose of 3-4 g/h, a dose somewhat higher than the one commonly used for preeclampsia [44]. If used at all, $\mathrm{MgSO}_{4}$ should be limited to $48 \mathrm{~h}$. The neuroprotective effect for the child, long suspected based on epidemiological data, is now also documented in a randomized study [45]. Due to remaining open questions, the use of magnesium sulfate as a neuroprotective agent can at this point not be recommended generally. If used, it should be administered during the last $24 \mathrm{~h}$ before delivery. The only welldocumented indication for intravenous magnesium sulfate administration to pregnant women remains the prophylaxis and treatment of seizures in preeclampsia and eclampsia.

\section{Regulatory approval of tocolytics}

In Switzerland, the beta-sympathomimetic hexoprenaline (Gynipral $^{\circledR}$ ) and the oxytocin antagonist atosiban (Tractocile ${ }^{\circledR}$ ) are approved for the treatment of preterm labor, while this is not the case for calcium antagonists, prostaglandin synthesis inhibitors, and nitrous oxide donors. If these are to be used, the patient has to be fully informed about their "offlabel" use and possible alternative treatments [46]. 


\section{Long-term tocolysis}

So far there is no clear evidence for the benefits of an oral long-term tocolysis with beta-sympathomimetics, oxytocin receptor agonists or calcium antagonists [47-50]. Routine long-term tocolysis can therefore not be recommended and should only be used in selected individual cases (i.e., with symptomatic placenta previa and early gestational age). In general practice, we frequently encounter individual cases where a continuation of tocolysis appears to have resulted in the prevention of preterm delivery. It is likely that the assumed benefits for the newborn in those instances cannot be statistically captured due to the small number of cases.

\section{Further measures}

\section{Bed rest}

A randomized study published in 1994 showed no effect of strict bed rest on the rate of preterm birth [51]. Because of the documented adverse effects associated with strict bed rest, such as an increased risk of thrombo-embolic events, more frequent depression or a feeling of isolation, there is generally no indication for ordering strict bed rest $[52,53]$. Prescription of modified bed rest and sick leave is acceptable.

\section{Bryophyllum}

A tocolytic effect of Bryophyllum pinnatum has been shown in vitro and in several observational reports or retrospective studies. Data from two prospective controlled studies (RCT) conducted according to the requirements of the regulatory agencies are pending. Further studies will be necessary to increase the evidence for its use as a tocolytic [54-56].

\section{Antibiotics}

There is no evidence that the administration of antibiotics to women with preterm labor and intact membranes lowers the rate of preterm birth [57]. Follow-up studies at 7 years have shown an increased risk of cerebral palsy in the same patient collective [58]. In selected cases, such as with preterm labor in the presence of a smear positive for group B streptococci, antibiotic is indicated even with intact membranes [59]. In women with preterm rupture of membranes before 34 weeks gestation, on the other hand, the administration of antibiotics (erythromycin, amoxicillin, clindamycin) results in a prolongation of the pregnancy and a reduction of neonatal morbidity [60].
Progesterone

According to a meta-analysis in 2012 , the prophylactic administration of vaginal progesterone (100-200 mg per day) to asymptomatic women with a singleton pregnancy and a cervical length of $<25 \mathrm{~mm}$, as well as to women with a prior preterm birth, reduced the rate of preterm delivery by $50 \%$ and favorably influenced perinatal morbidity and mortality (less RDS, less LBW). Progesterone did not work in twin or higher grade multiple gestations [61-66]. About the use of progesterone for the treatment of preterm labor, there is so far insufficient evidence-based information.

Conflict of interest The authors report no conflict of interest.

\section{References}

1. Bundesamt für Statistik aktuell (2010) Gesundheit der Neugeborenen 2008 Frühgeburten, Mehrlingsschwangerschaften und Wachstumsretardierung. wwwadminch

2. McCormick MC (1985) The contribution of low birth weight to infant mortality and childhood morbidity. $\mathrm{N}$ Engl J Med 312(2):82-90. doi:10.1056/NEJM198501103120204

3. Ness A, Visintine J, Ricci E, Berghella V (2007) Does knowledge of cervical length and fetal fibronectin affect management of women with threatened preterm labor? A randomized trial. Am J Obstet Gynecol 197(4):426 e1-426 e7. doi:S0002-9378(07)00884-8

4. Surbek D, D G, Irion O, Nelle M, Hösli I (2009) Lungenreifungsinduktion bei drohender Frühgeburt: Standardindikationen und Dosierung. SGGG Expertenbrief No 34

5. Goffinet F (2005) Primary predictors of preterm labour. BJOG 112(Suppl 1):38-47. doi:10.1111/j.1471-0528.2005.00583.x

6. Moreau C, Kaminski M, Ancel PY, Bouyer J, Escande B, Thiriez $G$ et al (2005) Previous induced abortions and the risk of very preterm delivery: results of the EPIPAGE study. BJOG 112(4):430-437. doi:10.1111/j.1471-0528.2004.00478.x

7. Gomez R, Galasso M, Romero R, Mazor M, Sorokin Y, Goncalves L et al (1994) Ultrasonographic examination of the uterine cervix is better than cervical digital examination as a predictor of the likelihood of premature delivery in patients with preterm labor and intact membranes. Am J Obstet Gynecol 171(4):956964. doi:0002-9378(94)90014-0

8. Crane JM, Van den Hof M, Armson BA, Liston R (1997) Transvaginal ultrasound in the prediction of preterm delivery: singleton and twin gestations. Obstet Gynecol 90(3):357-363. doi:S0029-7844(97)00277-9

9. Sonek JD, Iams JD, Blumenfeld M, Johnson F, Landon M, Gabbe S (1990) Measurement of cervical length in pregnancy: comparison between vaginal ultrasonography and digital examination. Obstet Gynecol 76(2):172-175

10. Schutte MF, Treffers PE, Kloosterman GJ, Soepatmi S (1983) Management of premature rupture of membranes: the risk of vaginal examination to the infant. Am J Obstet Gynecol 146(4): 395-400

11. Munson LA, Graham A, Koos BJ, Valenzuela GJ (1985) Is there a need for digital examination in patients with spontaneous rupture of the membranes? Am J Obstet Gynecol 153(5):562-563. doi:0002-9378(85)90474-0

12. Birkenmaier A, Ries JJ, Kuhle J, Burki N, Lapaire O, Hosli I (2012) Placental alpha-microglobulin-1 to detect uncertain 
rupture of membranes in a European cohort of pregnancies. Arch Gynecol Obstet. doi:10.1007/s00404-011-1895-9

13. Hassan SS, Romero R, Berry SM, Dang K, Blackwell SC, Treadwell MC et al (2000) Patients with an ultrasonographic cervical length $<$ or $=15 \mathrm{~mm}$ have nearly a $50 \%$ risk of early spontaneous preterm delivery. Am J Obstet Gynecol 182(6):1458-1467. doi:S0002-9378(00)81396-4

14. ACOG Practice Bulletin (2001) Assessment of risk factors for preterm birth. Clinical management guidelines for obstetriciangynecologists. Number 31, October 2001. (Replaces Technical Bulletin number 206, June 1995; Committee Opinion number 172, May 1996; Committee Opinion number 187, September 1997; Committee Opinion number 198, February 1998; and Committee Opinion number 251, January 2001). Obstet Gynecol 98(4):709-716

15. Kagan KO, To M, Tsoi E, Nicolaides KH (2006) Preterm birth: the value of sonographic measurement of cervical length. BJOG 113(Suppl 3):52-56. doi:10.1111/j.1471-0528.2006.01124.x

16. Chandiramani M, Di Renzo GC, Gottschalk E, Helmer H, Henrich W, Hoesli I et al (2011) Fetal fibronectin as a predictor of spontaneous preterm birth: a European perspective. J Matern Fetal Neonatal Med 24(2):330-336. doi:10.3109/14767058.2010. 496879

17. Crowley P (2000) Prophylactic corticosteroids for preterm birth. Cochrane Database Syst Rev (2):CD000065. 10.1002/14651858. CD000065

18. American College of O, Gynecologists, Committee on Practice B-O (2012) ACOG practice bulletin no. 127: management of preterm labor. Obstet Gynecol 119(6):1308-1317. doi:10.1097/ AOG.0b013e31825af2f0

19. Gyetvai K, Hannah ME, Hodnett ED, Ohlsson A (1999) Tocolytics for preterm labor: a systematic review. Obstet Gynecol 94(5 Pt 2):869-877

20. RCOG (2011) Tocolysis for women in preterm labour guidelines for the management of spontaneous preterm labour Green top clinical guideline No 1(B)

21. Conde-Agudelo A, Romero R, Kusanovic JP (2011) Nifedipine in the management of preterm labor: a systematic review and metaanalysis. Am J Obstet Gynecol 204(2):134 e1-134 e20. doi:10. 1016/j.ajog.2010.11.038

22. DGGG (2010) Leitlinien Medikamentöse Wehenhemmung bei drohender Frühgeburt

23. de Heus R, Mol BW, Erwich JJ, van Geijn HP, Gyselaers WJ, Hanssens $M$ et al (2009) Adverse drug reactions to tocolytic treatment for preterm labour: prospective cohort study. BMJ 338:b744

24. Herzog S, Cunze T, Martin M, Osmers R, Gleiter C, Kuhn W (1999) Pulsatile vs. continuous parenteral tocolysis: comparison of side effects. Eur J Obstet Gynecol Reprod Biol 85(2):199-204. doi:S0301211599000305

25. Anotayanonth S, Subhedar NV, Garner P, Neilson JP, Harigopal S (2004) Betamimetics for inhibiting preterm labour. Cochrane Database Syst Rev. (4):CD004352. doi: 10.1002/14651858. CD004352.pub2

26. The Worldwide Atosiban versus Beta-agonists Study Group (2001) Effectiveness and safety of the oxytocin antagonist atosiban versus beta-adrenergic agonists in the treatment of preterm labour. BJOG 108(2):133-142

27. Coomarasamy A, Knox EM, Gee H, Khan KS (2002) Oxytocin antagonists for tocolysis in preterm labour-a systematic review. Med Sci Monit 8(11):RA268-RA273

28. Romero R, Sibai BM, Sanchez-Ramos L, Valenzuela GJ, Veille JC, Tabor B et al (2000) An oxytocin receptor antagonist (atosiban) in the treatment of preterm labor: a randomized, doubleblind, placebo-controlled trial with tocolytic rescue. Am J Obstet Gynecol 182(5):1173-1183
29. Di Renzo GC, Roura LC (2006) Guidelines for the management of spontaneous preterm labor. J Perinat Med 34(5):359-366. doi:10.1515/JPM.2006.073

30. Tsatsaris V, Papatsonis D, Goffinet F, Dekker G, Carbonne B (2001) Tocolysis with nifedipine or beta-adrenergic agonists: a meta-analysis. Obstet Gynecol 97(5 Pt 2):840-847. doi:S0029784 400012126

31. King JF, Flenady VJ, Papatsonis DN, Dekker GA, Carbonne B (2003) Calcium channel blockers for inhibiting preterm labour. Cochrane Database Syst Rev. (1):CD002255. doi: 10.1002/ 14651858.CD002255

32. Haas DM, Caldwell DM, Kirkpatrick P, McIntosh JJ, Welton NJ (2012) Tocolytic therapy for preterm delivery: systematic review and network meta-analysis. BMJ 345:e6226

33. Papatsonis DN, Van Geijn HP, Ader HJ, Lange FM, Bleker OP, Dekker GA (1997) Nifedipine and ritodrine in the management of preterm labor: a randomized multicenter trial. Obstet Gynecol 90(2):230-234. doi:10.1016/S0029-7844(97)00182-8

34. Zimmermann R (2012) Handbuch Geburtshilfe

35. Silberschmidt AL, Kuhn-Velten WN, Juon AM, Zimmermann R, von Mandach U (2008) Nifedipine concentration in maternal and umbilical cord blood after nifedipine gastrointestinal therapeutic system for tocolysis. BJOG 115(4):480-485. doi:10.1111/j.14710528.2007.01630.x

36. Juon AM, Kuhn-Velten WN, Burkhardt T, Krahenmann F, Zimmermann R, von Mandach U (2008) Nifedipine gastrointestinal therapeutic system (GITS) as an alternative to slow-release for tocolysis-tolerance and pharmacokinetic profile. Eur J Obstet Gynecol Reprod Biol 140(1):27-32. doi:10.1016/j.ejogrb.2008. 02.003

37. Magee LA, Miremadi S, Li J, Cheng C, Ensom MH, Carleton B et al (2005) Therapy with both magnesium sulfate and nifedipine does not increase the risk of serious magnesium-related maternal side effects in women with preeclampsia. Am J Obstet Gynecol 193(1):153-163. doi:10.1016/j.ajog.2004.11.059

38. sapp.info (2010) Monographie Nifedipin. www sappinfo Monographie Nifedipin

39. Haas DM, Imperiale TF, Kirkpatrick PR, Klein RW, Zollinger TW, Golichowski AM (2009) Tocolytic therapy: a meta-analysis and decision analysis. Obstet Gynecol 113(3):585-594. doi:10. 1097/AOG.0b013e318199924a

40. King J, Flenady V, Cole S, Thornton S (2005) Cyclo-oxygenase (COX) inhibitors for treating preterm labour. Cochrane Database Syst Rev (2):CD001992. doi:10.1002/14651858.CD001992.pub2

41. Smith GN, Walker MC, Ohlsson A, O'Brien K, Windrim R (2007) Randomized double-blind placebo-controlled trial of transdermal nitroglycerin for preterm labor. Am J Obstet Gynecol 196(1):37 e1-37.e8. doi:10.1016/j.ajog.2006.10.868

42. Crowther CA, Hiller JE, Doyle LW (2002) Magnesium sulphate for preventing preterm birth in threatened preterm labour. Cochrane Database Syst Rev (4):CD001060. doi: 10.1002/ 14651858.CD001060

43. Grimes DA, Nanda K (2006) Magnesium sulfate tocolysis: time to quit. Obstet Gynecol 108(4):986-989. doi:10.1097/01.AOG. 0000236445.18265 .93

44. Jeyabalan A, Caritis SN (2002) Pharmacologic inhibition of preterm labor. Clin Obstet Gynecol 45(1):99-113

45. Rouse DJ, Hirtz DG, Thom E, Varner MW, Spong CY, Mercer $\mathrm{BM}$ et al (2008) A randomized, controlled trial of magnesium sulfate for the prevention of cerebral palsy. N Engl J Med 359(9):895-905. doi:10.1056/NEJMoa0801187

46. SGGG (2007) Expertenbrief No. 23 "Off Label Use" von Arzneimitteln in der Gynäkologie und Geburtshilfe

47. Lyell DJ, Pullen KM, Mannan J, Chitkara U, Druzin ML, Caughey $\mathrm{AB}$ et al (2008) Maintenance nifedipine tocolysis compared with placebo: a randomized controlled trial. Obstet 
Gynecol 112(6):1221-1226. doi:10.1097/AOG.0b013e31818d 8386

48. Dodd JM, Crowther CA, Dare MR, Middleton P (2006) Oral betamimetics for maintenance therapy after threatened preterm labour. Cochrane Database Syst Rev (1):CD003927. doi: 10. 1002/14651858.CD003927.pub2

49. Whitworth M, Quenby S (2008) Prophylactic oral betamimetics for preventing preterm labour in singleton pregnancies. Cochrane Database Syst Rev (1):CD006395. doi: 10.1002/14651858. CD006395.pub2

50. Papatsonis D, Flenady V, Liley H (2009) Maintenance therapy with oxytocin antagonists for inhibiting preterm birth after threatened preterm labour. Cochrane Database Syst Rev (1):CD005938. doi: 10.1002/14651858.CD005938.pub2

51. Sosa C, Althabe F, Belizan J, Bergel E (2004) Bed rest in singleton pregnancies for preventing preterm birth. Cochrane Database Syst Rev (1):CD003581. doi: 10.1002/14651858. CD003581.pub2

52. Heaman M, Gupton A (1998) Perceptions of bed rest by women with high-risk pregnancies: a comparison between home and hospital. Birth 25(4):252-258

53. Heaman MI, Blanchard JF, Gupton AL, Moffatt ME, Currie RF (2005) Risk factors for spontaneous preterm birth among Aboriginal and non-Aboriginal women in Manitoba. Paediatr Perinat Epidemiol 19(3):181-193. doi:10.1111/j.1365-3016.2005. 00644.x

54. Wachter R, Brenneisen R, Hamburger M, Mennet M, Schnelle M, Worel AM et al (2011) Leaf press juice from Bryophyllum pinnatum (Lamarck) Oken induces myometrial relaxation. Phytomedicine. doi:10.1016/j.phymed.2011.06.032

55. Plangger N, Rist L, Zimmermann R, von Mandach U (2006) Intravenous tocolysis with Bryophyllum pinnatum is better tolerated than beta-agonist application. Eur J Obstet Gynecol Reprod Biol 124(2):168-172. doi:10.1016/j.ejogrb.2005.05.013

56. Gwehenberger B, Rist L, Huch R, von Mandach U (2004) Effect of Bryophyllum pinnatum versus fenoterol on uterine contractility. Eur J Obstet Gynecol Reprod Biol 113(2):164-171. doi:10. 1016/S0301-2115(03)00370-1

57. King J, Flenady V (2002) Prophylactic antibiotics for inhibiting preterm labour with intact membranes. Cochrane Database Syst Rev (4):CD000246. doi: 10.1002/14651858.CD000246
58. Kenyon S, Pike K, Jones DR, Brocklehurst P, Marlow N, Salt A et al (2008) Childhood outcomes after prescription of antibiotics to pregnant women with spontaneous preterm labour: 7-year follow-up of the ORACLE II trial. Lancet 372(9646):1319-1327. doi:10.1016/S0140-6736(08)

59. Verani JR, McGee L, Schrag SJ (2010) Prevention of perinatal group B streptococcal disease-revised guidelines from CDC. MMWR Recomm Rep 59(RR-10):1-36

60. Kenyon SL, Taylor DJ, Tarnow-Mordi W, ORACLE Collaborative Group (2001) Broad-spectrum antibiotics for preterm, prelabour rupture of fetal membranes: the ORACLE I randomised trial. Lancet 357(9261):979-988. doi:S0140673600042331

61. Dodd JM, Flenady V, Cincotta R, Crowther CA (2006) Prenatal administration of progesterone for preventing preterm birth. Cochrane Database Syst Rev (1):CD004947. doi: 10.1002/ 14651858.CD004947.pub2

62. Hassan SS, Romero R, Vidyadhari D, Fusey S, Baxter JK, Khandelwal M et al (2011) Vaginal progesterone reduces the rate of preterm birth in women with a sonographic short cervix: a multicenter, randomized, double-blind, placebo-controlled trial. Ultrasound Obstet Gynecol 38(1):18-31. doi:10.1002/uog.9017

63. Romero R, Nicolaides K, Conde-Agudelo A, Tabor A, O'Brien JM, Cetingoz E et al (2012) Vaginal progesterone in women with an asymptomatic sonographic short cervix in the midtrimester decreases preterm delivery and neonatal morbidity: a systematic review and metaanalysis of individual patient data. Am J Obstet Gynecol 206(2):124 e1-124 e19. doi:10.1016/j.ajog.2011.12.003

64. Meis PJ, Aleman A (2004) Progesterone treatment to prevent preterm birth. Drugs 64(21):2463-2474

65. Sanchez-Ramos L, Kaunitz AM, Delke I (2005) Progestational agents to prevent preterm birth: a meta-analysis of randomized controlled trials. Obstet Gynecol 105(2):273-279. doi:10.1097/ 01.AOG.0000150559.59531.b2

66. Likis FE, Edwards DR, Andrews JC, Woodworth AL, Jerome RN, Fonnesbeck CJ et al (2012) Progestogens for preterm birth prevention: a systematic review and meta-analysis. Obstet Gynecol 120(4):897-907. doi:10.1097/AOG.0b013e3182699a15 